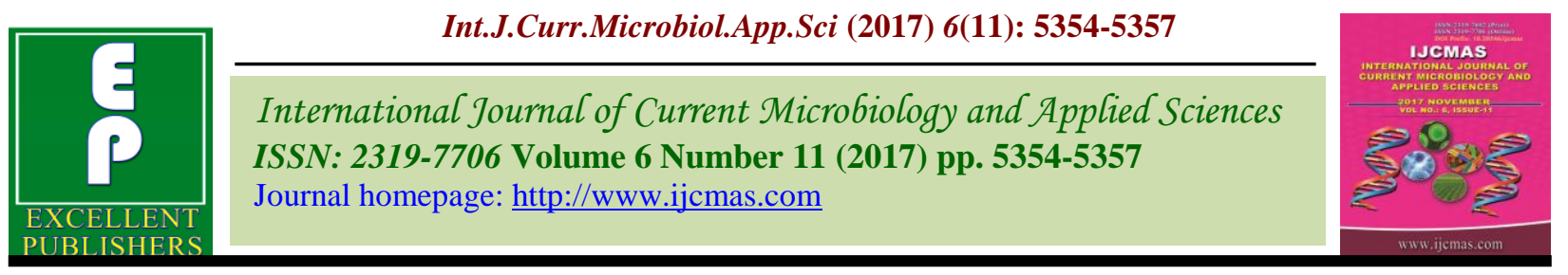

Original Research Article

https://doi.org/10.20546/ijcmas.2017.611.511

\title{
Effect of Method of Sowing on Bulb Size and Yield in Garlic
}

\author{
Amandeep Kaur, Manoj Sharma*, Jatinder Manan and Bindu
}

Krishi Vigyan Kendra, Kapurthala 144620, Punjab, India

*Corresponding author

\section{A B S T R A C T}

Keywords

Bulb size, Garlic, Method of sowing, Yield.

Article Info

Accepted:

30 September 2017

Available Online:

10 November 2017
The experiment was conducted on PG 17 variety of garlic at the Krishi Vigyan Kendra, Kapurthala farm during 2016-17. The cloves were planted both on beds and ridges at a spacing of $15 \mathrm{~cm} \times 7.5 \mathrm{~cm}$ and $12.5 \mathrm{~cm} \times 12.5$ $\mathrm{cm}$ in a 25 sqm plot for each treatment in RBD with 3 replications. Ten bulbs were selected randomly from each treatment. Significant differences were observed for number of clover, bulb diameter, fresh weight and dry weight. All the parameters gave better results in bed sowing irrespective of spacing. The garlic yield in bed sowing was comparatively less as compared to flat sowing but the bulb diameter was significantly higher in bed sowing, which in turn results in 30-40 per cent higher market price.

\section{Introduction}

Garlic (Allium sativum) is an important bulb crop most widely cultivated after onion (Hamma et al., 2013) and used both as spice and medicine. The cloves are used in flavoring foods and in preparing chutneys, pickles, curry powder, tomato ketchup etc. According to Geremew et al., (2010), planting techniques and spacing play important role in productivity of garlic. By altering spacing and method of planting the quality of bulbs, size and shape can be improved. When the spacing is less, the size of bulb is reduced without affecting the total yield because the total numbers of plants are more in per unit area. The bulb size of garlic increases with wide spacing but the net area yield does not increase. Meena and Gupta (2013) reported that none of the farmers were following the improved practices like soil treatment, seed rate and spacing in garlic cultivation. Keeping in view the above factors, the present study was conducted to find out the effect of method of planning on size and bulb yield in garlic.

\section{Materials and Methods}

\section{Climatic and soil requirements}

Garlic grows in a wide range of climatic conditions but cannot withstand too hot or cold weather. Extremely hot and long days are not conducive for bulb formation. Garlic requires sandy or clay loam soil, good drainage and a $\mathrm{pH}$ in the range of $6.0-8.4$. The crop raised in sandy soils cannot be kept for a long time and the bulbs are also lighter in weight. In heavy soils, the bulbs produced 
are deformed and during harvesting many bulbs are broken whereas in badly drained soils, garlic bulbs get discolored.

\section{Lay out of the experiment}

The experiment was conducted on PG 17 variety of garlic at the Krishi Vigyan Kendra, Kapurthala farm during 2016-2017. The cloves were planted both on beds and ridges

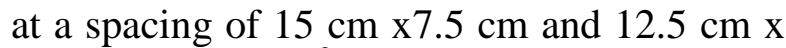
$12.5 \mathrm{~cm}$ in a $25 \mathrm{~m}^{2}$ plot for each treatment in randomized block design with three replications. Field was ploughed to prepare fine seed beds for sowing. A basal dose of $387 \mathrm{~kg} / \mathrm{ha}$ single super phosphate (SSP) was applied at the time of sowing and $275 \mathrm{~kg} / \mathrm{ha}$ urea was applied in three equal splits on 30 , 45 and 60 days after sowing.

Cloves were dibbled $7.5 \mathrm{~cm}$ deep, keeping their distal ends upwards and covered with thin layer of soil. First irrigation was given just after sowing and subsequent irrigations were given at $10 \mathrm{~d}$ intervals. The different treatments were $\mathrm{T} 1=$ Flat, $15 \mathrm{~cm} \times 7.5 \mathrm{~cm} ; \mathrm{T} 2=$ Flat, $12.5 \mathrm{~cm} \times 12.5 \mathrm{~cm} ; \mathrm{T} 3=\mathrm{Bed}, 15 \mathrm{~cm}$ $\mathrm{x} 7.5 \mathrm{~cm}$ and $\mathrm{T} 4=\mathrm{Bed}, 12.5 \mathrm{~cm} \times 12.5 \mathrm{~cm}$. the crop was harvested after 170 days after sowing. Ten bulbs were selected randomly from each treatment and data were collected on following parameters:

Plant height $(\mathrm{cm})$ - Plant height was measured with the help of measuring tape from soil surface to the top of plant.

Bulb size $(\mathrm{cm})$ - Bulb size was measured with the help of Vernier caliper.

Bulb fresh weigh (g) - Bulb fresh weight was recorded after harvesting with electronic balance.

Bulb dry weight (g) - Bulb dry weight was measured after drying in sun for one week with the help of electronic balance.
Number of cloves per bulb - Number of cloves was determined by counting the cloves per bulb in selected sample (10 bulbs).

Average yield (q/ha) - Yield was determined by weighing the collected bulbs from each plot and then yield per hectare was estimated.

The data were analyzed statistically by using OPSTAT (Sheoran et al.,, 1998).

\section{Results and Discussion}

\section{Bulb diameter}

It is an important quality parameter and different markets require different bulb sizes for different purposes. The data (Table 1) indicated that both planting methods and spacing significantly affected the bulb diameter. Maximum bulb diameter was observed in T4 $(4.5 \mathrm{~cm})$, which was at par with T3 and minimum was observed in T1 $(3.3 \mathrm{~cm})$. This was probably due to better aeration and drainage in bed sowing as compared to flat sowing. Similarly, wider spacing on beds provides more space for bulb growth and better light intensity leads to more bulb diameter. Similar results were reported by Kashay et al., (2014). It has been reported that closer spacing result in competition for nutrients and light, thus result in bulbs with less diameter (Biru, 2015) and small size of bulb (Kanthon et al.,, 2002).

\section{Bulb fresh weight and dry weight}

Significant differences were observed both for bulb fresh weight and dry weight. Maximum fresh weight and dry weight was recorded in T4 (35.6g and 17.2g) and minimum in $\mathrm{T} 1$ (18.5g and $7.9 \mathrm{~g})$. Bulb fresh weight increased in bed planting probably due to availability of adequate nutrients and favorable environment for growth as a result of which bulbs stored more food for vegetative as well as reproductive growth and thus accumulated 
more photosynthates. Similar results were reported by Bosekeng and Gesin (2015).

\section{Number of cloves per bulb}

The data regarding number of cloves per bulb differed significantly for all the treatments. Plant spacing plays an important role in increasing number of cloves per bulb. Maximum number of cloves were observed in treatment T3 (30.8) than T4 (29.0) followed by $\mathrm{T} 1$ (19.3) and minimum with T2 (17.5). It was noticed that in both flat and bed sowing, $15 \times 7.5 \mathrm{~cm}$ spacing produced maximum number of cloves per bulb but clove size was small due to less space available around each plant.

\section{Plant height}

The data (Table 1) showed that plant height significantly increased by plant spacing. Maximum plant height was observed in treatment $\mathrm{T} 4(61.3 \mathrm{~cm})$ whereas $\mathrm{T} 2(57.0 \mathrm{~cm})$ and T3 $(57.2 \mathrm{~cm})$ were at par with each other and minimum was in $\mathrm{T} 1(52.7 \mathrm{~cm})$.

More vegetative growth noted under wider spacing might be due to the fact that wider planting distance provided more space for growth and better light intensity which might have led to the increased photosynthesis resulting in more plant height. The results were in agreement with the findings of Ara et al., (2007).

Table.1 Effect of methods of sowing on bulb size and yield in garlic

\begin{tabular}{|l|c|c|c|c|c|c|}
\hline Treatment & $\begin{array}{l}\text { Bulb } \\
\text { diameter }(\mathbf{c m})\end{array}$ & $\begin{array}{l}\text { Bulb fresh } \\
\text { wt }(\mathbf{g})\end{array}$ & $\begin{array}{l}\text { Bulb dry } \\
\text { wt. }(\mathbf{g})\end{array}$ & $\begin{array}{l}\text { No. of } \\
\text { cloves }\end{array}$ & $\begin{array}{l}\text { Plant } \\
\text { height (cm) }\end{array}$ & $\begin{array}{l}\text { Yield } \\
\text { (q/ha) }\end{array}$ \\
\hline T1 Flat, 15x7.5cm & 3.3 & 18.5 & 7.9 & 19.3 & 52.7 & 112.83 \\
\hline T2 Flat, 12.5x12.5 & 3.7 & 24.0 & 11.0 & 17.5 & 57.0 & 110.17 \\
\hline T3 Bed, 15x7.5cm & 4.4 & 33.9 & 15.5 & 30.8 & 57.2 & 93.75 \\
\hline T4 Bed, 12.5x12.5 & 4.5 & 35.6 & 17.2 & 29.0 & 61.3 & 85.50 \\
\hline C.D. & $\mathbf{0 . 1}$ & $\mathbf{1 . 9}$ & $\mathbf{1 . 1}$ & $\mathbf{1 . 2}$ & $\mathbf{3 . 1}$ & $\mathbf{5 . 7 5}$ \\
\hline
\end{tabular}

Photo.1 Comparison of bulb size in flat v/s ridge methods of sowing

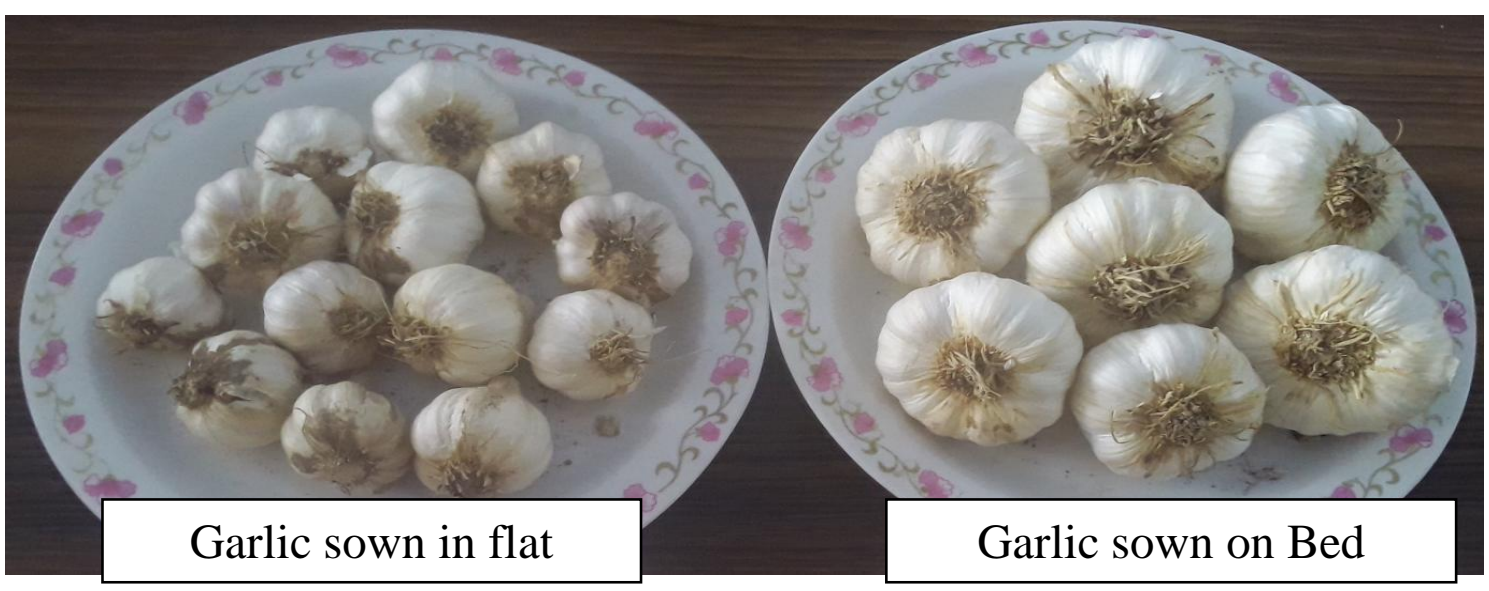

\section{Yield}

The method of plantings showed significant difference in yield per hectare of garlic.
Maximum yield was obtained in flat sowing as compared to bed sowing. The garlic yield in treatment $\mathrm{T} 1$ and $\mathrm{T} 2$ was at par with each other with $112.83 q$ and $110.17 q /$ ha, respectively. In 
bed sowing, yield was comparatively less. In treatment T3, yield recorded was $93.75 \mathrm{q} / \mathrm{ha}$ and in T4 it was $85.50 \mathrm{q} / \mathrm{ha}$. However, it was noticed that although all the parameters under study were better in $\mathrm{T} 4$ but yield was less which was due to low plant population per unit area which directly affected the yield.

More plant population with closer spacing in T1 increased the yield but decreases the quality of produce. It was worth to mention that the selling rate of a commodity in market depends upon the quality of a produce and if quality is not good, price will decrease which lowers the net returns to a farmer. Thus, it was important to go for optimum plant population in case of garlic cultivation in order to achieve better quality, yield and margin of profit.

The study revealed that in order to achieve maximum benefit from garlic cultivation, sowing of crop on bed planting with $15 \mathrm{~cm}$ $\mathrm{x} 7.5 \mathrm{~cm}$ spacing was found to be better over the flat sowing. Although, the yield in bed planting method was found to be comparatively less than flat method of sowing but quality of bulbs was better which fetched about 30 to 40 per cent higher selling price in the market compared to produce obtained from flat sowing due to small size of garlic bulbs.

\section{References}

Ara, N., Bashar M K, Begum and Kakon S 2007. Effect of spacing and pruning on growth and yield of tomato. Int J Sust Crop Prod 29(3): 35-39.

Biru, F.N., 2015. Effect of spacing and Nitrogen fertilizer on the yield component of Shallot (Allium ascalonium L.). J Bio 5(11):83-91.

Bosekeng, G., and Gesin GM 2015. Response of onion (Allium cepa L.) to sowing date and plant population. African J Agric Res 10(4): 179-187.

Geremew, A., Teshome A, Kasaye T and Amenti C 2010. Effect of intra row spacing on yield of three onion varieties at Adami Tulu Agricultural Research Centre. J Horti For 2(1): 7-11.

Hamma, L., Ibrahim U and Mohammed A B 2013. Growth, yield and economic performance of garlic (Allium sativum L.) as influenced by farm yard manure and spacing in Zaria, Nigeria. J Agric Econ Dev 2(1):1-5.

Kanthon, A.L., Abbey L, Hilla R G and Tabil M A 2002. Density effects plant development and yield of bulb onion (Allium cepa L.) in Northern Ghana. J Veg Crop Prod 8: 15-25.

Kashay, Y., Belew D and Abay F 2014. Effect of intra row spacing on plant growth and yield of onion varieties (Allium cepa). African $J$ Agric Res 9(10): 931-940.

Meena, K.C., and Gupta I N 2013. Impact of KVK training programmes on adoption of garlic production technology. J Krishi Vigyan 1(2): 41-43.

Sheoran, O.P., Tonk D S, Kaushik L S, Hasija R C and Pannu R S 1998. Statistical Software Package for Agricultural Research Workers. Recent Advances in information theory, Statistics and computer applications by D S Hooda and R C Hasija Department of Mathematics Statistics, CCSHAU, Hisar. Pp. 139-143.

\section{How to cite this article:}

Amandeep Kaur, Manoj Sharma, Jatinder Manan and Bindu. 2017. Effect of Method of Sowing on Bulb Size and Yield in Garlic. Int.J.Curr.Microbiol.App.Sci. 6(11): 5354-5357.

doi: https://doi.org/10.20546/ijcmas.2017.611.511 